\title{
Nierozróżniający wgląd w medytacji buddyzmu chan i jego wczesnobuddyjskie analogie
}

\author{
Kamil NOWAK*
}

\begin{abstract}
Undifferentiating insight in the Chan Buddhist meditation and its early Buddhist analogies: In the paper a comparative analysis of Chan Buddhist meditation and the early Buddhist meditation has been conducted. In the first part the meditational instructions present in Zuochan yi and the corresponding texts of Chinese Buddhism have been demonstrated. Subsequently, based on those texts, the ideal type of Chan Buddhist meditation is created. The second part consists of the analysis of Atthaka-vagga with the corresponding motifs from the other Pali Canon Suttas. The last part consists of a comparative analysis of the ideal type of Chan Buddhist meditation and meditation as shown in Atthaka-vagga. The whole of the analysis aims at demonstrating the topos common for the early Buddhist tradition and Chan Buddhism.
\end{abstract}

\section{KEYWORDS}

Chan Buddhism; early Buddhism; Zuochan yi; Atțhaka-vagga; meditation; calming; insight

* Mgr, doktorant w Instytucie Religioznawstwa Uniwersytetu Jagiellońskiego w Krakowie. E-mail: anthropos32@gmail.com. 
W pierwszym systematycznym opisie techniki medytacji siedzącej buddyzmu chan, jakim jest Zuochan yi (Zuòchán yí 坐禪儀, dalej ZCY), pojawia się następujący opis mentalnego aspektu medytacji: „Nie myśl o tym, co dobre, ani o tym, co złe. Gdy tylko pojawi się myśl, bądź uważny. Uważność skierowana na pojawiającą się myśl sprawi, że ona zniknie”2. W niniejszym artykule zamierzam ową instrukcję poddać interpretacji, ukazując jej szerszy kontekst, który obejmuje tradycję chan, jak również sutry i siastry mahajany, a następnie tak zinterpretowaną instrukcję zamierzam odnieść do wskazówek zawartych w Atthakawadze (p. Atțhaka-vagga), będącej jednym z najstarszych tekstów kanonu palijskiego. Celem owej analizy jest wykazanie zbieżności pomiędzy soteriologią buddyzmu chan a wczesnobuddyjską. Zbieżność ta pozwoli ukazać wspólny topos pojawiający się na przestrzeni łączącej wczesny buddyzm indyjski z rozwiniętą tradycją buddyzmu chan okresu dynastii Song (960-1279).

Tekst ZCY powstał na początku XII wieku. Pierwotnie podręcznik ów przeznaczony był przypuszczalnie dla świeckich buddystów, jednak z czasem zaczął funkcjonować także w środowisku monastycznym. Autorstwo tekstu przypisywane jest mnichowi Changlu Zongze (Chánglú Zōngzé 長蘆宗賾) (Schlütter, 2008: 169; Bielefeldt, 1986: 130-131). Technika medytacji opisana w ZCY była praktykowana w okresie dynastii Song (Schlütter, 2008: 169) oraz, co wynika

${ }^{1}$ Chińskie terminy źródłowe podaję kolejno w transkrypcji pinyin i w znakach tradycyjnych; terminy palijskie i sanskryckie podaję w transkrypcji IAST.

${ }^{2}$ Za thumaczeniem Carla Bielefeldta: „Do not think of any good or evil whatsoever. Whenever a thought occurs, be aware of it; as soon as you are aware of it, it will vanish” (Bielefeldt, 1986: 159-160); 一切善惡都莫思量。念起即覺。覺之即失。( T.48.2023.1047b28-29). Termin jué 覺 tłumaczony jest na język angielski dwojako, w zależności od kontekstu, jako awareness lub enlightenment; oznacza on bowiem zarówno stan umystu występujący podczas medytacji, jak i różne rodzaje oświecenia (pierwotne oświecenie běnjué 本覺, doskonałe oświecenie yuánjué 圓覺 itd.). Dosłowne przetłumaczenie terminu awareness jako „świadomość nie oddałoby jednak w pełni znaczenia terminu jué 覺 w kontekście analizowanych w niniejszym artykule tekstów; co więcej sugerowałoby tożsamość jué 覺 z terminem shí 識, który w kontekście buddyzmu również tłumaczony jest jako „świadomośc” (ang. consciousness), a posiada odmienne (a w pewnych aspektach przeciwstawne) znaczenie niż jué 覺. Termin jué 覺 kojarzy się z trzeźwością umysłu, przytomnością, czujnością, unaocznieniem. W moim odczuciu terminem, który najlepiej oddaje znaczenie jué 覺 w kontekście analizowanych tekstów źródłowych, jest dobrze zadomowiony w buddyjskiej terminologii termin „uważność”. Nie jest to jednak propozycja doskonała, bowiem „uważność” jest tłumaczeniem angielskiego wyrażenia mindfulness, a to z kolei stanowi tłumaczenie palijskiego terminu sati, jakie w XIX wieku zaproponował Rhys Davids (Gethin, 2011: 263). Termin sati natomiast tłumaczony jest w tekstach źródłowych buddyzmu chińskiego jako niàn 念 (w niniejszym artykule jako „myśli”, za najczęstszym angielskim tłumaczeniem jako thoughts), a niàn 念 określa stan umysłu, do którego zaniku prowadzi jué 覺 (!). Pojęcie niàn 念 jest zatem przeciwstawione pojęciu jué 覺. Pomimo tego terminologicznego nieładu termin jué 覺 w znaczeniu, jakie występuje w analizowanych w artykule instrukcjach, jest analogiczny do terminu sati rozumianego jako mindfulness, co postaram się wykazać w dalszych rozważaniach. 
z dużej liczby analogicznych opisów z wcześniejszego piśmiennictwa buddyzmu chan, przypuszczalnie w okresie dynastii Tang (618-907), a być może od samego początku istnienia tradycji chan.

ZCY jest tekstem krótkim, liczącym w chińskim oryginale niewiele ponad tysiąc znaków. Generuje to liczne problemy interpretacyjne. Te wynikające z jego lakoniczności mogą zostać jednak rozwiązane wskutek rozwinięcia poszczególnych fragmentów ZCY poprzez odniesienie ich do paralelnych fragmentów $\mathrm{z}$ innych tekstów chan, jak również tekstów tradycji tiantai (tiāntái 天台) i innych dzieł, które znacząco wpłynęły na rozwój buddyzmu chan. Podobnej analizy ZCY dokonał Carl Bielefeldt (Bielefeldt, 1986), ukazując w ten sposób szerszy kontekst zawartych w podręczniku instrukcji. Tego typu metoda została niejako zasugerowana przez samego autora ZCY, który w jednym z fragmentów odsyła czytelnika do innych dzieł, takich jak Śurangamasutra (s. Sürangama-sūtra; Lèngyán jīng 楞嚴經), traktat autorstwa Zongmiego (Guîfēng Zōngmì 圭峰宗密, 780-841), będący komentarzem do Sutry doskonałego oświecenia (Yuánjué jīng 圓覺經), oraz tekst szkoły tiantai ${ }^{3}$.

Do tekstów tradycji chan ukazujących szerszy kontekst instrukcji zawartych w ZCY zaliczam głównie teksty przynależące do wczesnego okresu buddyzmu chan, do wschodniej góry (dōngshān 東山), szkoły północnej (Bielefeldt, 1986: 139), szkoły południowej (Bielefeldt, 1986: 144), szkoły hongzhou (bóngzbōu 洪州) oraz szkoły caodong (cáodòng 曹洞) (Schlütter, 2008: 172). Dodatkowo, w celu ukazania jeszcze szerszego kontekstu omawianych treści, posługuję się tekstami, które nie zostały napisane w środowisku buddystów chan, ale które odegrały bardzo znaczącą rolę w rozwoju chanu. Są to przede wszystkim dzieła, takie jak Wzbudzenie wiary w mabajanę (Dàshéng qǐxin lùn 大 乘起信論) i najważniejsze sutry mahajany, które wpisały się na stałe w historię buddyzmu chan.

Zacytowany fragment instrukcji zawartych w ZCY wskazuje na dwa aspekty praktyki. Pierwszym z nich jest zatrzymanie myślenia (silliang 思量), które rozróżnia na to, co dobre (shàn 善), i to, co złe (è 惡). Drugim aspektem jest uważność (jué 覺) ukierunkowana na te myśli (niàn 念), które już się pojawiły. Dzięki uważności myśli, na które jest ona ukierunkowana, zanikają.

Instrukcja ta posiada stosunkowo liczne analogie w innych tekstach buddyzmu chan i tekstach pośrednio związanych z ową tradycją. Zalecenie wyzbycia się rozróżniania (fēnbié 分別) (X.63.1217.1a24) pojawia się już w Traktacie o dwóch wejściach i czterech praktykach (Ėrù sixing lún 二入四行論) przypisywanym przez tradycję chan, jak również przez większość badaczy, Bodhidharmie (McRae, 1986: 101). Owo nierozróżnianie, występujące w traktacie,

${ }^{3}$ Jest to Mohe zhiguan lub Xiao zhiguan — obydwa autorstwa Zhiyi (Zhiyì 智顗, 538-597). Drugi z owych tekstów wykazuje więcej podobieństw do Zuochan yi (Bielefeldt, 1986: 132). O wpływie Xiao zhiguan i działalności Zongmiego na rozwój technik medytacyjnych buddyzmu chan zob. Faure, 1997: 51. 
dotyczy dychotomii, takich jak: ja (zì 自) — inny (tā 他) (X.63.1217.1a22-23), święty (shèng 聖) — świecki (fán 凡) ${ }^{4}$.

W podobne instrukcje obfituje Inskrypcja o wierze w umyst (Xinxin ming 信心铭) (Watson, 1993: 148-152) przypisywana przez tradycję trzeciemu patriarsze, Sengcanowi (Jiànzhì Sēngcàn 鑑智僧燦). Wymienia ona dychotomie, takie jak właściwe (sbi 是) - niewłaściwe (fèi 非) (T.48.2010.376c5), spokój (jì 寂) — zamęt (luàn 亂) (T.48.2010.376c19), dobre (băo 好) — złe (ě 惡) (T.48.2010.376c19), byt (yǒu 有) — niebyt (wú 無) (T.48.2010.377a6-7), najmniejsze (jíxiǎo 極小) — największe (jídà 極大) (T.48.2010.377a5-6). Charakterystyczne jest to, że w Xinxin ming dualistyczne poglądy (èrjiàn 二見) (T.48.2010.376c4) związane są z afektami, bowiem stanowią ich podstawę. Dualistyczne, rozróżniające poglądy skutkują więc pojawieniem się pragnienia i niechęci, zatem zgodnie $\mathrm{z}$ buddyjską doktryną prowadzą do powstania cierpienia.

Kolejnym tekstem, w którym odnajdujemy podobne treści, jest przypisywany piątemu patriarsze, Hongrenowi (Dàmăn Hóngrěn 大滿弘忍), Traktat o podstawach kultywacji umystu (Xiūxinn yào lún 修心要論). Podobnie jak w ZCY, w tekście tym adept jest instruowany, aby zatrzymał dualistyczne myślenie (wszelkiego rodzaju, bez wyszczególniania pojedynczych dychotomii), a następnie kontemplował strumień świadomości, który, w wyniku tej kontemplacji, uspokoi się i zniknie ,jak poryw wiatru” (McRae, 1986: 130). Podobieństwo do instrukcji z ZCY jest wyraźne.

Innym dziełem, w którym można odnaleźć opis praktyki medytacyjnej zbliżony do tego z ZCY, jest Sutra podwyższenia (Tán jing 壇經), która zgodnie z tradycyjnym poglądem zawiera nauki Huinenga (Huinéng 慧能), znanego jako Szósty Patriarcha (Liù Zǔ 六祖). W edycji tekstu z okresu dynastii Yuan (1271-1368) (McRae, 2000: 45), jak również we wczesnej edycji z Dunhuang (Yampolsky, 1967: 140), pojawia się opis siedzącej medytacji (zuòchán 坐禪) $\mathrm{w}$ formie metaforycznej interpretacji dwóch terminów składających się na tę nazwę. W myśl tej interpretacji praktyka „siedzenia” polega na zaprzestaniu aktywności umysłu polegającej na rozróżnianiu dobra (shàn 善) i zła (è 惡) (T.48.2008.353b19). Medytacja (chán 禪) natomiast jest rozumiana jako „wewnętrzne widzenie własnej nieporuszonej natury” (nèijiàn zixing bú dòng 內見自性不動) (T.48.2008.353b20).

Również w tekstach przypisywanych wpływowemu propagatorowi szkoły południowej, jakim był Heze Shenhui (Hézé Shénhui 荷澤神會), pojawiają się instrukcje bardzo podobne do tych z ZCY. Jest w nich mowa o tym, aby, gdy tylko pojawi się myśl (niàn 念), być uważnym (jue 覺) ${ }^{5}$. Skutkiem tego zanika

${ }^{4}$ X63.1217.1a23; Andrew Ferguson tłumaczy jako sacred and profane (Ferguson, 2000: 18); John McRae jako ordinary person and sage (McRae, 1986: 103); Jeffrey Broughton jako common man and sage (Broughton, 1999: 9).

${ }^{5}$ Użyto tych samych terminów co w ZCY. 
zarówno sama myśl, jak i uważność, którą została ona objęta. Shenhui kładzie nacisk na to, iż tylko owa uważność (jué 覺) może zatrzymać powstałe myśli, a każdy wysiłek mający na celu ich zatrzymanie jest jedynie tworzeniem kolejnych myśli (Bielefeldt, 1986: 144).

$\mathrm{Na}$ konieczność porzucenia dualistycznych, wartościujących myśli wskazuje także szkoła hongzhou. Jej założyciel i najbardziej wpływowy przedstawiciel, Mazu (Mǎzŭ Dàoyī 馬祖道一, 709-788), w jednej ze swoich mów podaje instrukcje, zgodnie z którymi należy zaprzestać podążania za dobrem (shàn 善) i odrzucania zła (è 惡), ponieważ jest to intencjonalne działanie mające za podstawę myślenie (niàn 念) oraz skutkujące wytworzeniem stanu narodzin i śmierci (Jia, 2006: 126).

Instrukcje analogiczne do zawartych w ZCY można odnaleźć również w literaturze pośrednio związanej z buddyzmem chan (poprzez wpływ wywierany na tę tradycję). Tekstem, z którego treści czerpie chan i w którym przedstawiono podobny do występującego w ZCY opis praktyki medytacyjnej, jest Sutra doskonatego oświecenia $a^{6}$ W jej rozdziale siódmym występuje opis trzech rodzajów medytacji (s. śamatha, samāpatti, samādhi). Pierwsza z nich, czyli śamatha, opisana jest jako praktyka polegająca na uspokojeniu wszystkich myśli (niàn 念) i na utrzymywaniu uważności (jué 覺) skierowanej na przepływ zjawisk. Wskutek utrzymywania owej uważności dochodzi do wygaśnięcia ciała, umysłu i zewnętrznych obiektów (Muller, 2003).

Również we Wzbudzeniu wiary w mabajane - tekście, na którym w dużej mierze opiera się koncepcja umysłu funkcjonująca w buddyzmie chan — znajdujemy podobny opis praktyki medytacyjnej. Polega ona na przyjęciu w cichym miejscu wyprostowanej pozycji siedzącej i zaprzestaniu wzbudzania myśli (niàn 念). Praktykujący tę formę medytacji nie powinien skupiać umystu na żadnym obiekcie ${ }^{7}$. Należy się pozbyć wszelkiej myśli razem z myślą o pozbywaniu się myśli (Hakeda, 2006: 91). Praktyka zaprzestania wzbudzania myśli powinna być wykonywana w parze z praktyką kontemplacji (guàn 觀) powstających i zanikających myśli (niàn 念), które generują cierpienie (kと̌ 苦) (T.32.1666.582c15-17) (Hakeda, 2006: 94). Innymi słowy, myśli nie należy wzbudzać; jeśli jednak jakaś zostanie wzbudzona, należy kontemplować jej przepływ. Obie praktyki są przedstawione jako nierozerwalne i konieczne do wyzwolenia (Hakeda, 2006: 95).

\footnotetext{
${ }^{6}$ Podobieństwo to wiąże się zapewne z faktem, iż Zongze nawiązuje do tej sutry, odsyłając czytelnika do komentarza do niej w kwestiach pojawienia się Mary podczas medytacji. Ponadto sutra owa cieszyła się wśród buddystów chan dużym uznaniem. Przyczynił się do tego niezwykle wpływowy przedstawiciel szkoły heze (bézé 菏泽) i huayan (buáyán 華嚴), Zongmi (zob. Gregory, 2002: 54-58).

${ }^{7}$ Jako potencjalne obiekty medytacji tekst wymienia oddech, kolor, formę, przestrzeń, ziemię, wodę, ogień, wiatr oraz to, co usłyszane, ujrzane, zapamiętane, wyobrażone (Hakeda, 2006: 91).
} 
Podobny opis medytacji można odnaleźć jeszcze w Mohe zhiguan (Móbē zhĭguàn 摩訶止觀), będącym opus magnum Zhiyi. Autor opisuje w owym tekście, jako jedno z czterech samadhi, praktykę zwaną „samadhi ani chodzenia, ani siedzenia” (fèixíng fēizuò sānmèi 非行非坐三昧) lub „samadhi uważności mentalnej aktywności” (juéyì sānmèi 覺意三昧). Jest to instrukcja, zgodnie z którą należy objąć uważnością (jué 覺) każdą rodzącą się mentalną aktywność (yì 意), unikając przy tym jej analizy (skąd pochodzi i jakie jest jej przeznaczenie) (Bielefeldt, 1988: 80; Stevenson, 1986: 75-84).

Wydaje się, iż ważnym źródłem inspiracji dla przedstawionych powyżej opisów, zarówno tych formalnie przynależących do szkoły chan, jak i tych, z których chan czerpał, jest Sutra diamentowa (s. Vajracchedikā-prajñāpāramitā-sūtra; Jingōang bōrēbōluómiduōjing 金剛般若波羅蜜多經), a konkretnie jej rozdział dziesiąty, mówiący o stanie umysłu, który nie jest "osadzony” (zhù 住) w żadnej z sześciu sfer (s. āyatana), czyli w żadnym z pięciu zmystów, jak również w konceptualizacji (Conze, 2001: 45). Warto wspomnieć, że zgodnie z tym, co podaje tradycja chan, Huineng miał osiągnąć przebudzenie, wysłuchawszy tego właśnie fragmentu Sutry diamentowej. Interesujące, że w komentarzu do omawianego fragmentu, przypisywanym Szóstemu Patriarsze, pojawia się wskazówka, aby wyzbyć się dyskutowania na temat dobrych i złych cech innych osób (Cleary, 1998: 109), co przywodzi na myśl przedstawione powyżej opisy stanu umysłu wolnego od dualizmu dobra i zła.

Innym tekstem niewątpliwie stanowiącym źródło dla aspektu medytacji, jakim jest zatrzymanie dualistycznej aktywności umysłu, jest dziewiąty rozdział Sutry Wimalakirtiego (s. Vimalakìrti-nirdeśa-sūtra; Wéimójié suǒshuō jing 維摩詰所說經), w którym rozmaici bodhisattwowie wymieniają po kolei różne pary przeciwieństw, które zostają każdorazowo zanegowane poprzez rozpoznanie ich współzależności, a ostateczny poziom zaniku dualizmu zostaje przedstawiony jako wykraczający poza konceptualizację (słynne milczenie Wimalakirtiego) (McRae, 2004: 143-148).

Owo nierozróżnianie na przeciwstawne pojęcia występuje w literaturze chan pod różnymi terminami. Stosunkowo często (jeśli nie najczęściej) pojawiającym się określeniem jest wúfēnbié 無分別. Pojęcie to jest tłumaczeniem sanskryckiego terminu nirvikalpa (Soothill \& Hodous, 2014: 378; Suzuki, 1999: 417), występującego często $\mathrm{w}$ połączeniu z terminem jñāna (s. nirvikalpa-jūāna). Termin nirvikalpa-jñāna kojarzony jest głównie z tradycją jogaciary (s. yogācāra), w której oznacza niekonceptualne, bezpośrednie poznanie takości (s. tathatā) (Suzuki, 1999: 106), stanowiące najwyższą formę wyzwalającego poznania (Willis, 2000: 184). Poznanie to posiada cechy ponadświatowości (s. lokottara), bowiem wykracza poza trzy sfery (s. tri-dhātu) buddyjskiego kosmosu (Lusthaus, 2006: 173). Sam termin vikalpa, stanowiący przeciwieństwo terminu nirvikalpa, wywodzi się ze źródłosłowu oznaczającego między innymi 
porządkowanie, natomiast etymologicznie spokrewniony termin kalpana wskazuje na twórczość literacką (Griffiths, 1990: 85-86.). Vikalpa oznacza, oprócz rozróżniania na opozycyjne kategorie, także imaginację, wyobrażanie sobie czegoś (Griffiths, 1990: 86). Odzwierciedla to koncepcję jogaciary o mentalnej naturze wszystkiego, co istnieje. Dualistyczna aktywność umysłu warunkuje więc istnienie wszystkiego, co dane, a jej zatrzymanie prowadzi do wyzwolenia z uwarunkowanej egzystencji. Bliski związek wúfēnbié 無分別 z jogaciarą potwierdza fakt przetłumaczenia przez Paramarthę (s. Paramārtha, 499-569) terminu nirvikalpa właśnie jako wúfēnbié 無分別 w chińskim przekładzie jednego z najważniejszych tekstów jogaciary, jakim jest Trzydzieści strof (s. Trimísikā-kārikā) Wasubandhu (s. Vasubandhu) (Lusthaus, 2006: 292, 294). Wpływ zarówno Paramarthy, jak i nurtu jogaciary na kształtowanie się tradycji chan był przemożny (Paul, 1984: 4, 13).

$\mathrm{Na}$ podstawie przedstawionych fragmentów, kierując się przekonaniem, iż stanowią one różne opisy w ogólnym zarysie tej samej formy praktyki, można podjąć się stworzenia typu idealnego medytacji siedzącej, którą opisuje ZCY i paralelne fragmenty wymienionych tekstów. Praktyka ta składa się z dwóch elementów. Pierwszym z nich jest wyciszenie myśli, które rozumiane są jako wszelkie aktywności umysłu, mające naturę rozróżniania na przeciwstawne pojęcia (na przykład dobro-zło, ja-inny, byt-niebyt) i które prowadzą do pojawienia się pragnienia lub niechęci wobec desygnatów tych dychotomicznych pojęć, a skutkiem tego do cierpienia. Ten element praktyki polega na niewzbudzaniu myśli, które jeszcze nie powstały. Drugim elementem jest wgląd, którego funkcją jest rozpoznanie nietrwałości, pustki, braku własnej niezależnej natury owych myśli. Skutkiem owego rozpoznania powstałe myśli same zanikają. Obydwa elementy przedstawiane są jako nierozłączne.

Czy w literaturze wczesnego buddyzmu można odnaleźć odpowiednik zarysowanego powyżej typu idealnego medytacji buddyzmu chan? Odpowiednik tego rodzaju pojawia się we wspomnianym zbiorze szesnastu krótkich tekstów pod tytułem Ațthaka-vagga (dalej AV) lub w skrócie Atțhaka. Zbiór ten jest częścią Suttanipaty (p. Sutta-nipāta) i wchodzi w skład Khuddakanikaji (p. Khuddaka-nikāya) kanonu palijskiego. AV jest interesująca w kontekście niniejszych rozważań z kilku powodów. Po pierwsze, będąc uważaną za jeden z najwcześniejszych tekstów buddyjskich, jest reprezentatywna dla wczesnego buddyzmu. Po drugie stanowi jedyną część Suttanipaty, która znajduje się również w chińskich agamach (Vetter, 1988: 101) i, co istotne, wersja chińska jest niemal identyczna z wersją palijską (Burford, 1992: 39). Po trzecie AV była tekstem wpływowym zarówno w Indiach, jak i w Chinach (Burford, 1992: 39). Po czwarte zawiera opisy kojarzące się z apofatycznym językiem wielu fragmentów literatury chan. Skojarzenie jest na tyle silne, że badacz zbioru, Luis Gómez, zasugerował, iż może istnieć związek historyczny AV z indyjskim „protochanem” (Gómez, 2005: 198). 
Treść AV, tak jak ją przedstawia Grace Burford, skupia się na opisie człowieka ${ }^{8}$, który podąża ścieżką praktyki buddyjskiej i urzeczywistnia jej owoce. Człowiek ów jest uważny (p. sata, satimā), posiada wiedzę (p. paññā, ñatvā, jānāti, veda, vidvā). Wiedzy tej towarzyszy nieporuszoność, wewnętrzny spokój (p. sama, upekkbā). Człowiek ten wolny jest od pożądania i lgnięcia (Burford, 1992: 41-43).

AV wyróżnia jeden szczególny obiekt przywiązania — jest nim pogląd (p. ditthi). Utrzymywanie określonego poglądu jest jedną z form, w jakich przejawia się przywiązanie. Człowiek wybiera taki pogląd, który harmonizuje z jego pragnieniami; taki, który je uzasadnia i wzmacnia. Konsekwencją posiadania poglądu wraz z emocjonalnym do niego stosunkiem jest angażowanie się $\mathrm{w}$ dysputy i kłótnie, w trakcie których dany pogląd jest broniony (Burford, 1992: 44). Wzmacniając pożądanie i lgnięcie, pogląd prowadzi ostatecznie do cierpienia. Człowiek zatem nie powinien zajmować żadnego stanowiska.

Pogląd w AV ukazany jest jako aktywność umysłowa polegająca na preferowaniu jednego obiektu i odrzucaniu obiektu stanowiącego przeciwieństwo preferowanego. Ma on zatem charakter rozróżniającej, dualistycznej aktywności umysłu, tworzącej przeciwstawne wobec siebie pojęcia. AV wyszczególnia różne pary przeciwieństw: część IV tekstu zawiera przeciwieństwo zasługi i zła (Norman, 1992: 92); część VI mówi o rozróżnieniu na przyjemne i nieprzyjemne (Norman, 1992: 94); część IX wyszczególnia w kontekście opisu poglądu takie dychotomiczne kategorie, jak lepszy i gorszy (oraz stan pośredni), a także prawda i fałsz (Norman, 1992: 97-98); część XIII zawiera dwie pary pojęć — godny potępienia i nieskazitelny oraz czysty i nieczysty (Norman, 1992: 103).

Człowiek, który nie czyni rozróżnienia na przeciwstawne pojęcia, utrzymuje umysł w stanie wewnętrznego spokoju (p. upekkbā) (Sn. 4.978) (Norman, 1992: 104) — w stanie równowagi wykraczającej poza podział na odczucia przyjemne i nieprzyjemne. Ów wewnętrzny spokój występuje w AV w wyraźnym kontekście praktyki medytacyjnej (p. jhāna) (Sn. 4.978) (Norman, 1992: 110). Sugeruje to związek pozbywania się poglądów z praktyką wyciszenia medytacyjnego. Na medytacyjny kontekst treści AV wyraźnie wskazują również inne fragmenty (Norman, 1992: 105-106).

Połączenie terminów upekkbā i jbāna odsyła do klasycznych schematów stopni wyciszenia medytacyjnego, jakie odnajdujemy w rozmaitych suttach kanonu palijskiego. W Suttapitace wyróżnić można kilka modeli dźhany: model ośmioetapowy, model siedmioetapowy, pięcioetapowy, czteroetapowy (Vetter, 1988: XX; Hung, 2010: 14-33). Pierwszy z nich, czyli model składający się z ośmiu etapów, wyróżnia następujące poziomy zaawansowania w praktyce dźhany: dźhany od pierwszej do czwartej korespondujące ze sferą formy (p. rūpa) oraz dźhany korespondujące ze sferą braku formy (p. arūpa), zwane także samāpatti.

\footnotetext{
${ }^{8}$ Burford używa określenia „osoba doskonała” (ideal person) (Burford, 1992: passim).
} 
Cztery rodzaje samāpatti to: nieskończona przestrzeń (p. ākāsānañcāyatana), nieskończona świadomość (p. viñ̃āanañ cāyatana), nicość (p. ākiñncañ̃nāyatana) oraz ani percepcja, ani nie-percepcja (p. nevasaññānāsañ̃āalatana). Model siedmioetapowy składa się z powyższych elementów bez ostatniego, czyli bez ani percepcji, ani nie-percepcji. Model pięcioetapowy składa się z czterech dźhan formy oraz stanu wygaszenia percepcji i odczuć ( $\mathrm{p}$. sañña-vedayita-nirodba). Model czteroetapowy natomiast mieści w sobie wyłącznie dźhany sfery formy.

Wspólną cechą wymienionych powyżej modeli wyciszenia medytacyjnego jest obecność kanonicznej listy czynników dźhany (p. jbānañga), które stopniowo są wyciszane w miarę doskonalenia praktyki w obrębie sfery formy (p. rūpa). Wszystkich czynników jest pięć. Są to: myśl zainicjowana (p. vitakka), myśl podtrzymywana (p. vicāra), zachwyt (p. piti), radość (p. sukba), ujednopunktowienie (p. ekaggatā) umysłu lub wewnętrzny spokój (p. upekkbā) (Paravahera Vajiranana Mahathera, 2010: 30-32). Czynniki owe wyciszane są w miarę przechodzenia do coraz bardziej subtelnych poziomów medytacji. W ramach przejścia od pierwszej do drugiej dźhany zanikają dwa pierwsze, czyli zainicjowana i podtrzymywana myśl. Przy przejściu do kolejnej dźhany zanika zachwyt, a w czwartej dźhanie nie występuje już radość. Pozostaje w niej jedynie ujednopunktowienie umystu i/lub wewnętrzny spokój.

Jak wynika z powyższych schematów, upekkbā w ramach modelu czteroelementowego stanowi kwintesencję procesu medytacyjnego wyciszania umysłu. Po osiągnięciu czwartego etapu wyciszenia, w obrębie modelu czteroelementowego, adept wzbudza wyzwalający wgląd w cztery szlachetne prawdy i/lub dwanaście ogniw powstawania $\mathrm{w}$ zależności, skutkiem czego dostępuje wyzwolenia. Związek wyciszenia medytacyjnego z wglądem potwierdzają liczne sutty kanonu palijskiego ${ }^{9}$. Jeśli chodzi o tego rodzaju związek przedstawiony w AV, upekkbā występuje w parze z terminem sati (Sn. 4.861, Sn. 4.978-979) (Norman, 1992: 99, 110), który odsyła zarówno do wyciszenia, jak i do wglądu medytacyjnego. Treść wglądu medytacyjnego nie jest jednoznacznie przedstawiona w AV, więc konieczne jest odniesienie się do pola znaczeniowego terminu sati w kanonie palijskim. Kontekstem występowania terminu sati są kanoniczne listy obiektów medytacyjnych, na bazie których praktykowane jest skupienie medytacyjne, jak również rozwijany wgląd. Listę obiektów medytacyjnych wczesnego buddyzmu przedstawia przede wszystkim niezwykle wpływowy tekst kanonu palijskiego, jakim jest Satipațthānā-sutta (MN 10) oraz nieco dłuższa wersja tego samego tekstu, czyli Mahā-satipatțhānā-sutta (DN 22). W owych tekstach zaproponowane zostały następujące kategorie obiektów medytacji: ciało (p. kāya), odczucia (p. vedanā), umysł (p. citta), zjawiska (p. dhamma). W skład kategorii obiektów cielesnych wchodzą takie szczegółowe podkategorie, jak:

\footnotetext{
${ }^{9} \mathrm{Na}$ temat związku wyciszenia z wglądem we wczesnym buddyzmie zob. Gombrich, 2006: 96-134.
} 
oddech (p. ānāpāna), cztery pozycje ciała (chodzenie, stanie, siedzenie, leżenie), rozmaite czynności cielesne (jedzenie, picie, noszenie ubrań), „nieczystości” (rozmaite części ciała, takie jak paznokcie, włosy czy narządy wewnętrzne), cztery żywioły, dziewięć medytacji „cmentarnych” (kontemplacja zwłok w dziewięciu fazach rozkładu). W ramach kategorii odczuć mieszczą się trzy podkategorie: odczucia przyjemne (p. sukba), nieprzyjemne (p. dukkba) i neutralne (p. adukkhamasukba). Kategoria umysłu obejmuje stany mentalne, takie jak pragnienie (p. rāga), awersja (p. dosa) i niewiedza (p. moba). Kategoria zjawisk z kolei mieści w sobie następujące grupy: pięć przeszkód (p. nīvarana), pięć skupisk (p. kbandba), sześć podstaw (p. àyatana), siedem czynników oświecenia (p. bojjbanga) oraz cztery szlachetne prawdy (p. ariya-sacca).

Powyższy schemat pojawia się również w innych tekstach palijskich (Gethin, 2003: 355). Co ważne funkcjonuje on także w wersji chińskiej — głównie w chińskim przekładzie MN 10 z pewnymi jednak rozbieżnościami w stosunku do wersji palijskiej ${ }^{10}$. Co więcej liczne analogie do obiektów medytacyjnych opisanych w MN 10 i DN 22 można odnaleźć również we wczesnych chińskich sutrach medytacyjnych ${ }^{11}$. Znajomość kanonicznych obiektów medytacyjnych w ramach chińskiego buddyzmu była zatem porównywalna do tej, która występuje we wczesnym buddyzmie indyjskim.

Aspekt wglądu, jaki ukazuje MN 10, występuje w obrębie wszystkich czterech kategorii obiektów medytacyjnych (ciało, uczucia, umysł, zjawiska) i polega na rozpoznaniu nietrwałości danego obiektu (jego powstawania i zanikania) (Ñānamoli \& Bodhi, 2012: 146, 149-154). Skutkiem owego rozpoznania, umysł medytującego przestaje lgnąć do „czegokolwiek na świecie” (Ñānamoli \& Bodhi, 2012: 146, 149-154). Uogólniając opis medytacji zawarty w MN 10 oraz DN 22 i rozpatrując go w świetle $\mathrm{AV}$, można zauważyć, iż aspekt wglądu w nietrwałość odnosi się do wszystkiego, co dane w świadomości, a co ujmują cztery kategorie obiektów medytacyjnych. Adept rozpoznaje nietrwałość każdego zjawiska.

Treść $A V$, rozpatrzona w kontekście satipatthany i etapów dźhany oraz ujęta w formie typu idealnego, wskazuje na formę medytacji, w ramach której dochodzi do zatrzymania aktywności umysłowej polegającej na kategoryzowaniu rzeczywistości w oparciu o rozmaite opozycje binarne - jest to aspekt wyciszenia. Owemu aspektowi towarzyszy wgląd w nietrwałość, niesubstancjalność zjawisk. Polem wglądu jest całość danych świadomościowych. Wgląd i wyciszenie prowadzą do pozbycia się pożądania i lgnięcia, a skutkiem tego do wyzwolenia $\mathrm{z}$ uwarunkowanej egzystencji.

Nakreśliwszy dwa typy idealne praktyki medytacyjnej, można przejść do komparatystki owych typów. Zbieżności dają się wykazać przede wszystkim

\footnotetext{
${ }^{10}$ Różnice między wersją palijską a chińską MN 10 w formie tabelarycznej wyszczególnione są w: Kuan, 2008: 166-169.

11 Tabela porównująca listy obiektów medytacyjnych wczesnych chińskich sutr medytacyjnych została zamieszczona w: Yuanci, 2012: 447.
} 
na poziomie krytycznego stosunku do rozróżniającej aktywności umysłu. Obie tradycje postulują powstrzymanie dualistycznego myślenia $\mathrm{w}$ aspekcie epistemologii (prawda-fałsz) i aksjologii (dobro-zło). Warto też uwzględnić aspekt ontologiczny, który występuje w buddyzmie chan pod postacią dychotomii byt-niebyt, ale który nie pojawia się w AV. Niemniej owa para przeciwieństw odgrywa istotną rolę w kontekście opisu drogi środkowej przedstawionej w nikajach. Wykraczanie poza rozróżnienie na byt i niebyt jest głównym motywem wpływowego w kontekście madhjamaki (Fuller, 2005: 64) tekstu, jakim jest Kaccāyanagotta-sutta ${ }^{12}$. Można jednak odnieść wrażenie, iż dualistyczne myślenie ma charakter całościowy i wskazuje nie na wybrane obiekty poznania, ale raczej na zasadę funkcjonowania umysłu. Zawarte w literaturze źródłowej opisy opozycji binarnych mają jedynie charakter egzemplifikacyjny i rozróżniająca aktywność umysłu bynajmniej się do nich nie ogranicza, ale obejmuje każdą dającą się pomyśleć parę przeciwieństw.

W obydwu analizowanych tradycjach zatrzymanie rozróżniającej aktywności umysłu stoi w parze z wglądem, którego treść stanowi nietrwałość zjawisk, ich samoistne zanikanie. Wyciszenie dualistycznego myślenia i wgląd w nietrwałość stanowią zatem dwa aspekty jednej praktyki medytacyjnej i razem prowadzą adepta ku wyzwoleniu od przywiązania, a skutkiem tego — od cierpienia właściwego dla uwarunkowanej egzystencji.

Warto zwrócić uwagę na paradoksalny charakter występującej w tradycji chan i w AV praktyki pozbywania się poglądów ${ }^{13}$. Wszak już sam postulat porzucania poglądów jest wynikiem utrzymywania adekwatnego poglądu, a stwierdzenie, że wszystkie poglądy należy odrzucić, jest wewnętrznie sprzeczne. Co więcej u podstawy praktyki buddyjskiej wyrażonej schematem ośmiorakiej ścieżki leży utrzymywanie właściwego poglądu (p. sammā-ditțhi). Ponadto odrzucenie rozróżnienia na prawdę i fałsz podważa zasadność buddyjskiej praktyki, której istotą jest przecież rozwijanie wglądu w to, co można nazwać prawdą. Odrzucenie z kolei rozróżnienia na dobro i zło podważa niezwykle złożony i przemyślany system buddyjskiej etyki, tak fundamentalnej dla całej tradycji.

Analizowane teksty bynajmniej nie rezygnują z powyższych aspektów buddyjskiej ścieżki. Wgląd pojawia się już w samych analizowanych w artykule instrukcjach. Etyka również odgrywa fundamentalną rolę. ZCY rozpoczyna się od zalecenia wzbudzenia współczucia wobec czujących istot i powzięcia ślubowania dążenia do wyzwolenia ich wszystkich (Bielefeldt, 1986: 159), a AV wskazuje na konieczność utrzymywania buddyjskich zasad

${ }^{12}$ Co warto odnotować, w chińskiej wersji sutty „byt” i „niebyt” to yǒu 有i wú 無 (T2.99.85c21). Tych samych terminów używa autor Inskrypcji o wierze w umyst na określenie jednej z par przeciwieństw (T48.2010.377a6-7).

${ }_{13}$ Paradoksalny charakter poglądów poddaje szczegółowej analizie Paul Fuller (Fuller, 2005). Celem zapoznania się z rozmaitymi próbami rozwiązania owego paradoksu, jakie poczynili badacze, zob. Fuller, 2005: 4-7. 
etycznych (Norman, 1992: 109). Ponadto obydwa dzieła zostały włączone do zbiorów tekstów, których treść ma w tym kontekście duże znaczenie. ZCY stanowi część Chanyuan qinggui (Chányuàn qīnggū 禪苑清規) - zbioru reguł klasztornych buddyzmu chan (Schlütter, 2008: 169; Bielefeldt, 1986: 130-131; por. Yifa, 2002: 109-110). Ów tekst, opisując regułę klasztorną, w całości bazuje na rozróżnieniu na to, co właściwe i niewłaściwe. AV jest natomiast częścią kanonu palijskiego, którego jednym z koszy jest Vinaya, czyli również zbiór rozmaitych reguł klasztornych.

Myślę, iż charakter instrukcji zawartych w ZCY i AV jest paradoksalny jedynie z pozoru. Stosunkowo łatwo można go rozwiązać przy uwzględnieniu medytacyjnego kontekstu owych instrukcji. Powstrzymanie dualistycznego myślenia ma miejsce w stanie wyciszenia medytacyjnego osiąganego w trakcie medytacji siedzącej. Gdy dany adept kończy praktykę medytacji siedzącej i wraca do swojego codziennego życia, na powrót zaczyna posługiwać się dualistycznymi kategoriami. Jedyne, co powinno ulec w tym względzie zmianie, to uzyskanie dzięki medytacji wiedzy o konwencjonalnej naturze owych dychotomii oraz redukcja emocjonalnego przywiązania do nich. Owe dychotomie w pewnym sensie jednak pozostają, bowiem stanowią warunek konieczny funkcjonowania człowieka w sferze prawdy konwencjonalnej (p. sammuti-sacca).

Istnieje wiele aspektów medytacji, które są właściwe tylko dla stanu medytacyjnego. Przykładowo wyciszenie myśli zainicjowanej i podtrzymywanej przy przechodzeniu od pierwszego do drugiego poziomu skupienia medytacyjnego sprawia, że przestaje istnieć warunek konieczny posługiwania się mową. W medytacji powyżej pierwszej dźhany nie występuje zdolność mowy. Nie oznacza to jednak, że tradycja buddyjska rezygnuje z mowy także poza praktyką medytacji. Liczba około 52 milionów chińskich znaków, jakimi zapisana jest Tripitaka Koreana, świadczy o tym dobitnie. Stosunek do mowy przypomina stosunek buddyzmu do dualistycznego myślenia, które nota bene umożliwia funkcjonowanie mowy. Współzależność ta została ukazana we wspomnianej już Sutrze Wimalakirtiego. Tytułowy Wimalakirti na przestrzeni całej narracji nie stroni bynajmniej od mowy. Jako niezrównany mówca udziela porad i nagan arhatom oraz prowadzi równe dysputy z Mańdziuśrim. Kiedy jednak zostaje poproszony o opisanie zasady niedualności, pogrąża się w milczeniu.

\section{BIBLIOGRAFIA}

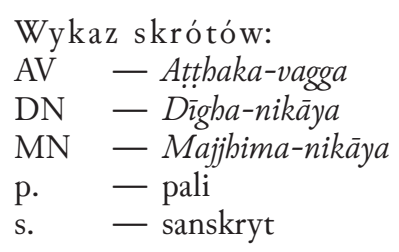


Sn. - Sutta-nipāta

T — Taishō Shinshū Daizōkyō

X - Xuzang jing (Manji Shinsan Dainibon Zokuzōkyō)

ZCY - Zuochan yi

Teksty źródłowe:

Cleary, Th. (Tłum.). (1998). The sutra of Hui-neng, grand master of Zen. Boston-London: Shambhala Publications.

Dasheng qixin lun 大乘起信論 (T.32.1666). On-line: http://www.cbeta.org/result/normal/ T32/1666_001.htm (dostęp: 11.02.2016).

Erru sixing lun 二入四行論 (X.63.1217). On-line: http://www.cbeta.org/result2/normal/ X63/1217_001.htm (dostęp: 11.02.2016).

Hakeda, Y. (Tłum.). (2006). The awakening of faith, attributed to Asvaghosha. New York: Columbia University Press.

Katyayānagotra-sütra (T02.99.85c17-86a3). On-line: http://www.cbeta.org/result/normal/ T02 /0099_012.htm (dostęp: 18.02.2016).

Mabā-satipațțhānāa-sutta. On-line: http://www.tipitaka.org/romn/ (dostęp: 25.09.2017)

McRae, J. (Tłum.). (2000). The platform sutra of the Sixth Patriarch. Berkeley: Numata Center for Buddhist Translation and Research.

McRae, J. (Tłum.). (2004). The Vimalakirti sutra. Berkeley: Numata Center for Buddhist Translation and Research.

Muller, Ch. (Thum.). (2003). The sutra of perfect enlightenment (Yuanjue jing). On-line: http:// www.acmuller.net/bud-canon/sutra_of_perfect_enlightenment.html (dostęp: 13.01.2015).

Muller, Ch. (Tłum.). (2013). The diamond sutra. On-line: http://www.acmuller.net/budcanon/diamond_sutra.html (dostęp: 13.01.2015).

Ñānamoli, Bhikkhu \& Bodhi, Bhikkhu (Tłum.). (2012). The middle length discourses of the Buddha. Kandy: Buddhist Publication Society.

Norman, K. R. (Ttum.). (1992). The group of discourses. Oxford: The Pali Text Society.

Sutta-nipāta. On-line: http://www.tipitaka.org/romn/ (dostęp: 18.02.2016).

Tan jing 壇經 (T48.2008). On-line: http://www.cbeta.org/result/normal/T48/2008_001.htm (dostęp: 11.02.2016).

Walshe, M. (Tłum). (1995). The long discourses of the Buddha. Boston: Wisdom Publications.

Watson, B. (Ttum.). (1993). On trust in the mind (s. 148-152). W: S. Bercholz \& Sh. Ch. Kohn (Red.). Entering the Stream. Boston: Shambhala.

Xinxin ming 信心铭 (T48.2010). On-line: http://www.cbeta.org/result/normal/ T48/2010_001.htm (dostęp: 11.02.2016).

Yampolsky, Ph. (Tłum.). (1967). The platform sutra of the Sixth Patriarch. New York-London: Columbia University Press.

Zuochan yi 坐禪儀 (T48.2023.1047b11-1047c20). On-line: http://www.cbeta.org/result/ normal/T48/2023_001.htm (dostęp: 11.02.2016).

Opracowania:

Bielefeldt, C. (1986). Ch'ang-lu Tsung-tse's Tso-Ch'an I and the „secret” of Zen meditation (s. 129-161). W: P. Gregory (Red.). Traditions of meditation in Chinese Buddhism. Honolulu: Kuroda Institute.

Bielefeldt, C. (1988). Dogen's manuals of Zen meditation. Berkeley: University of California Press.

Broughton, J. (1999). The Bodhidharma anthology. Berkeley-Los Angeles: University of California Press. 
Burford, G. (1992). Theravāda Buddhist soteriology and the paradox of desire (s. 37-61). W: R. Buswell \& R. Gimello (Red.). Patbs to liberation. Honolulu: University of Hawai i Press.

Conze, E. (2001). Buddhist wisdom. New York: Vintage Books.

Faure, B. (1997). The will to orthodoxy. Stanford: Stanford University Press.

Ferguson, A. (2000). Zen's Chinese heritage. Boston: Wisdom Publications.

Fuller, P. (2005). The notion of dittthi in Theravāda Buddhism. London-New York: Routledge.

Gethin, R. (2003). The Buddhist path to awakening. Oxford: Oneworld Publications.

Gethin, R. (2011). On some definitions of mindfulness. Contemporary Buddhism, 12/1, 263-279.

Gombrich, R. (2006). How Buddhism began. Abingdon-New York: Routledge.

Gómez, L. (2005). Proto-Mādhyamika in the Pali canon (s. 182-212). W: P. Williams (Red.). Buddhism: Critical concepts in religious studies (t. 4). Abingdon-New York: Routledge.

Gregory, P. (2002). Tsung-Mi and the sinification of Buddhism. Honolulu: University of Hawaii Press.

Griffiths, P. (1990). Pure consciousness and Indian Buddhism (s. 71-97). W: R. K. Forman (Red.). The problem of pure consciousness. New York: Oxford University Press.

Hung, Y. (2010). Issues in Śamatha and Vipaśyanā: A comparative study of Buddhist meditation. Rosemead: University of the West. (Nieopublikowana praca doktorska).

Jia, J. (2006). The Hongzhou School of Chan Buddhism. Albany: State University of New York Press.

Kuan, T. (2008). Mindfulness in early Buddhism: New approaches through psychology and textual analysis of Pali, Chinese and Sanskrit sources. Abingdon-New York: Routledge.

Lusthaus, D. (2006). Buddhist phenomenology. Abingdon-New York: Routledge-Curzon.

McRae, J. (1986). The Northern School and the formation of early Ch'an Buddhism. Honolulu: Kuroda Institute.

Paravahera Vajiranana Mahathera (2010). Buddhist meditation in theory and practice. Charleston: Charleston Buddhist Fellowship.

Paul, D. (1984). Pbilosophy of mind in sixth-century China. Stanford: Stanford University Press.

Schlütter, M. (2008). How Zen became Zen. Honolulu: Kuroda Institute.

Soothill, W. E. \& Hodous, L. (2014). A dictionary of Chinese Buddhist terms. Abingdon-New York: Routledge.

Stevenson, D. (1986). The four kinds of Samādhi in early T'ien-t'ai Buddhism (s. 45-97). W: P. Gregory (Red.). Traditions of meditation in Chinese Buddhism. Honolulu: Kuroda Institute.

Suzuki, D. T. (1999). Studies in the Lankavatara Sutra. Delhi: Motilal Banarsidass Publishers.

Vetter, T. (1988). The ideas and meditative practices of early Buddhism. Leiden: E. J. Brill.

Willis, J. D. (2000). On knowing reality: The Tattvārtha chapter of Asanga's Bodhisattvabhūmi. Delhi: Motilal Banarsidass Publishers.

Yifa (2002). The origins of Buddhist monastic codes in China. Honolulu: Kuroda Institute.

Yuanci (2012). A study of the meditation methods in the DESM and other early Chinese texts (s. 438-465). W: Khammai Dhammasami et al. (Red.). Buddhist pbilosophy and meditation practice. Academic papers presented at the 2nd IABU Conference Mabacbulalongkornrajavidyalaya University, Main Campus Wang Noi, Ayutthaya, Thailand. Bangkok: Mahachulalongkornrajavidyalaya University Press. 